UDC 94 (=792.54) «1941-1944»

DOI: $10.24919 / 2519-058 x .12 .177559$

\title{
Oksana SALATA
}

PhD hab. (History), Professor, Head of the Department of Ukraine's History of Borys Grinchenko Kyiv University, 18/2 Bulvarno-Kudriavska Street, Kyiv, Ukraine, postal code 04053 (o.salata@kubg.edu.ua)

ORCID: https://orcid.org/0000-0003-2498-1483

\section{Оксана САЛАТА}

доктор історичних наук, професор, завідувач кафедри історії Украӥни Київського університету імені Бориса Грінченка, вуличя Бульварно-Кудрявська 18/2, Київ, Україна, індекс04053 (o.salata@kubg.edu.иа)

Бібліографічний опис статті: Salata, O. (2019). Activity of the Odessa opera and ballet theatre. Skhidnoievropeiskyi Istorychnyi Visnyk [East European Historical Bulletin], 12, 137-148. doi: 10.24919/2519-058x.12.177559

\section{ACTIVITY OF THE ODESSA OPERA AND BALLET THEATRE IN AUGUST 1941 - 1942}

Summary. The purpose of the study. It is pointed out, that the cultural life of Ukrainian citizens during the German and Romanian occupation of 1941 - 1942 is an important historical page of the Second World War. The activity of the Odessa Opera and Ballet Theater, which has always been in the spotlight of historical science, is being revealed. The research methodology. The research methodology is based on the principles of historicity, objectivity and scientific capacity. In the article analyzed the scientific development of the problem in the national and foreign historiography. The basic conceptual approaches for studying the problem are defined. This work has a scientific novelty in the context of foreign historiography. The activity of the Odessa Opera and Ballet Theater are an important part of the heritage of the national and world theater art. The identified period of study-August 1941-1942 is explained by the most favorable conditions of occupation time, when the cultural and theatrical life of Odessa was actively developing. Changes in theatrical life and work of actors began when the situation on the fronts for the German and Romanian troops deteriorated. Despite the above, this period has become important in the history of Ukrainian theaters: the achievements and complexities that they have experienced. Special attention in the process of research was found in the materials of the periodical «Odessa newspaper». During the work and analysis at the material, special historical methods of research were used, such as: the historical and comparative method, that made it possible to reveal the characteristic features of the activity of Ukrainian theaters during the occupation and the historical-system, by which it was possible to reveal the activities of the Odessa Opera and Ballet Theater changes of the theatrical staff attitude and repertoire. The scientific novelty. Important in this context was the activity of the theater staff during the Romanian occupation of Odessa in August $1941-A u$ gust 1942. is to reveal the peculiarities of the activities of the Odessa Opera and Ballet Theater under conditions of the Romanian occupation regime in August 1941 - August 1942, based on the materials of the periodical «Odessa newspaper» and archival materials. Conclusions. It is underlined the reasons for which the theatrical staff of the Odessa Opera and Ballet Theater could not move deep into the Soviet Union before occupation. Actors in the difficult conditions of the occupation regime turned their creativity into a true theatrical art, which kept domestic traditions and borrowed the experience of the luminaries of the world-class opera and ballet. The theater became an artistic center, where famous European actors and singers came. The role of the periodicals in the coverage of the Odessa Opera and Ballet Theater was determined. Establishment of the occupation regime the activities of the 
Romanian occupation administration the conditions in which actors worked; the study of memoirs and local periodicals shows the interest and support of the inhabitants of the city of the Odessa Opera and Ballet Theater and the interaction of the theatrical collective with the actors of foreign theaters of world importance and the preservation of its national artistic traditions.

Key words: Transnistrian governorate, Romanian occupation regime, Odessa Opera and Ballet Theater, opera, ballet, actors, artistic theater heritage, periodicals.

\section{ДІЯЛЬНІСТЬ ОДЕСЬКОГО ТЕАТРУ ОПЕРИ ТА БАЛЕТУ В СЕРПНІ 1941 - 1942 pp.}

Анотація. Мета дослідження. Показано, що культурне життя Украӥнських громадян у період німецької та румунської окупації 1941 - 1942 рр. є важливою сторінкою історії Другої світової війни. Розкривається діяльність Одеського театру опери та балету, яка завжди була у колі уваги історичної науки. Важливою у иььому контексті стала діяльність колективу театру в період румунської окупачії Одеси у серпні 1941 - серпні 1942 рр. Методологія дослідження. В основі методології дослідження лежать приниипи історизму, об'єктивності та наукової спроможності. У статті проаналізовано стан наукової розробленості проблеми у вітчизняній та зарубіжній історіографії. Визначено основні концептуальні підходи до вивчення проблеми. Представлена наукова робота має наукову новизну в контексті зарубіжної історіографіï. Діяльність Одеського театру опери та балету с важливою складовою у спадщині вітчизняного та світового театрального мистецттва. Визначений нами період дослідження - серпень 1941 1942 рр. пояснюється найсприятливішим за умов окупаиії часом, коли культурне та театральне життя Одеси активно розвивалося. Зміни у театральному житті і творчості акторів почалися, коли ситуачія на фронтах для німецьких та румунських військ погіршилася. Незважаючи на вищезазначене, цей період став важливим в історії діяльності украйнських театрів. Особлива увага у проиесі дослідження виявилася до матеріалів періодичного видання «Одеська газета». Під час їх збирання й аналізу використовувалися спеціально-історичні методи дослідження, а саме: історично-порівняльний метод, який дав можливість виявити характерні риси діяльності украӥнських театрів в умовах окупаиії та історико-системний, за допомогою якого вдалося розкрити діяльність Одеського театру опери та балету, зміни в настроях колективу театру $i$ репертуару. Наукова новизна полягає у розкритті особливостей діяльності колективу Одеського театру опери та балету в умовах румунського окупаційного режиму у серпні 1941 - серпні 1942 років за матеріалами періодичного видання «Одеська газета» та архівними матеріалами. Висновки. Показано причини, за яких творчий колектив Одеського театру опери та балету не зміг виїхати углиб Радянського Союзу перед окупацією міста. Актори в складних умовах окупаиійного режиму перетворили свою творчість на справжн театральне мистецтвво, яке зберігало вітчизняні традицї та запозичувало досвід корифеїв опери та балету світового рівня. Театр став мистецьким центром, куди приїздили відомі європейській актори і співаки. Визначено роль періодичних видань у висвітленні діяльності Одеського театру опери та балету. Встановлення окупаційного режиму, діяльність румунської окупачійної адміністрації, умови, в яких готував і показував вистави колектив театру; через дослідження спогадів та місиевих періодичних видань показано інтерес і підтримку жителями міста діяльності Одеського театру опери та балету, взаємодію театрального колективу з акторами зарубіжних театрів світового значення, збереження ним національних мистецьких традицій.

Ключові слова: губернаторство «Трансністрія», румунський окупачійний режим, Одеський театр опери та балету, опера, балет, актори, мистецька театральна спадщцина, періодична npeca.

The problem statement. In order to reproduce the complete historical picture of the events of the Second World War, it is necessary to study all the components of this global event. Particularly important, in our opinion, is the cultural life of Ukrainian citizens during the German and Romanian occupation of 1941 - 1944. In view of this, the activities of the Odessa Opera and Ballet Theater require in-depth study. An important aspect of this 
problem is the life and activity of the theater actor in the difficult conditions of the Romanian occupation of Odessa and its interaction with world masters.

Analysis of recent research and publications. The cultural life of the inhabitants of the Transnistrian governorate and the history of the Odessa Opera and Ballet Theater was studied by some national and foreign scholars in particular the activities of the theatrical staff and its individual actors during the interwar period and during the Second World War were discussed by M. Poisner (Poisoner, 2004, pp. 136-137), F. Samoilov (Samoilov, 2010. p. 547). The place of the Odessa Opera and Ballet Theater among the famous theaters of the world and the popularity of his plays were researched by A. Artyomov and I. Ignatkin (Ignatkin, 1969). The role of theatrical art in the life of Odessa was shown in researches by Maksymenko V. C. (Maksymenko). Important to the study were the memories of the famous Irish scientist Michael Forsyth, a designer of concert halls, an architect and violinist, who explored the influence of musical taste and style on architecture and the mutual influence of buildings and their acoustics on musical performance and composition. His attention in this context attracted the Odessa Opera and Ballet Theater (Forsythe, 1985). The role of spectacular art and its research in domestic and foreign historiography in the context of attracting theaters to the propaganda activities of the occupation administration was considered by Salata O. In her work, she showed that most historians in their studies paid little attention to the study of the reasons for involving theaters in public life during the occupation period $1941-1942$ (Salata, p. 56).

The article's purpose. Disclosure of the peculiarities of the activities of the Odessa Opera and Ballet Theater under the conditions of the Romanian occupation regime in August 1941 - August 1942, based on the materials of the periodical «Odessa newspaper» and archival materials.

The statement of the basic material. During the troubles of this terrible war of the twentieth century theaters continued to work as in occupation and in the deep rear. Theatrical teams that did not have time to go deep into the Soviet Union were forced to adapt to the new conditions and continue their activities in the territory occupied by the Romanian troops. This period also became important in the history of Ukrainian theaters. We have no right to ignore these achievements and difficulties. It's significant to recreate an objective picture of the theater team's activities during the Romanian occupation regime in August 1941 June 1942, in particular the Odessa Opera and Ballet Theater.

In August 1941, Odessa was occupied by the German-Romanian troops. When the troops reached the city the military command of the Odessa defense district appointed a special anti-aircraft unit. A special order was given to defend the theater building from bombing as a valuable architectural monument. On the roofs of the houses near the theater were installed guns that did not silent all 73 days and nights - from August 5 to October 16, 1941, while the city's defense was continued. However, despite these actions one of the enemy highexplosive bombs still hit the lobby of the western facade and partially damaged the portico.

The director of the theater Snebrovsky (from August 5 to October 16, 1941), while the Odessa defense operation lasted, did not leave the theater for a minute.

In fact that the Odessa Opera House was considered to be of great value not only for society, but also as part of the world's historical heritage. Describing the interior of the Odessa Opera and Ballet Theater, Kateryna Astafyeva, on the pages of the historic Dilettant magazine, says: «The interior is not inferior to the exterior of the theater. The audience room is designed in the late French rococo style. Ornaments, gilding, stucco molding - all this, 
combined with a large crystal chandelier and a sufficient number of chandeliers and fixtures, creates a tremendous effect». She also notes that on the ceiling of the ceiling depicted scenes from four works of Shakespeare: «The Sleep of the Summer Night», «Hamlet», «Winter Tale» and «How Do You Like It» (Astafeva).

The elegance of the front and the interior of the theater was also noted by well-known Russian bassist Fedir Chaliapin. For the first time, having visited the Odessa Opera and Ballet Theater, he wrote to his wife: «I was in the theater and came to the wild delight of the beauty of the theater. I've never seen anything more beautiful in my life». And Olena Obraztsova once said that she considered the Odessa Theater the best,in comparison with the Vienna Opera itself! (Astafeva, 2018).

Thus during the whole period of the Romanian occupation the Odessa Opera and Ballet Theater continued to operate uninterruptedly. The peculiarity of the theater's activity during this period is defined by the realities of the occupation regime. The works of the German and Romanian authors were necessarily included in the repertoire. But despite this fact there were Russian and Ukrainian classics performances. The theater hall was never empty due to the fact that the ticket prices were low (Theater during the Great Patriotic War).

In the first months of the war the theater was forced to suspend its activities. Some actors went to the front, others stayed in the city confused waiting for what would happen to them and their families.

It lasted several months, and on December 13, 1941, the Odessa Opera and Ballet Theater, despite the war and occupation resumed its work again. The decision was made by the general meeting of the theater's collective, which was about a hundred people as in the prewar period. The director of the theater was the tenor D. Seliavin.

In Transnistria governor Romanian Army Commander Ion Antonescu brought civil administration. Head of Administration was appointed civilian governor who had control. The Transnistria Territory was divided into 13 administrative districts, which were guided by district prefectures headed by heads of administrations - prefects. The owls were divided into areas where the organs of management were called district pretorias headed by the praetors. Pretors of districts were subordinated to the county prefect (State archive of Odessa region, f. 2249, d. 3, c. 97, p. 4). The districts, in turn, were divided into communes consisting of one large or several small settlements. At the head of the commune there was a village council a prymar, led by a prymar (Dizanova, 2016, p. 49).

With the formation of Transnistria - an administrative and political unit in the southwest of modern Ukraine, which the German leadership, under the Treaty in Bendery of August 30, 1941, granted the temporary Romanian civilian administration (Bolovan), Odessa and the Odessa region began to be considered Romanian territory.

On behalf of the Romanian government Commander of the 4th Romanian Army, General I. Yakobich, referring to Odessa citizens, said: «Citizens of Odessa! Be calm! No one will bring evil to the peaceful people, who can continue to work quietly and which will adhere to all published orders. All sacred rights will be granted to you and all temples will be opened. Measures will be taken to provide food, preserve your health, and those that will ensure the preservation of your life and property. We advise you not to carry out unfriendly acts in relation to the army and officials who will control the city» (Istoriya Bessarabii i Yuga Ukrainyi, 2016).

Odessa was a very important city in the plans of the Romanian government. Therefore, the Marshal of the Kingdom of Romania, Jon Antonescu, appointed Odessa Mayor Hermann 
Pintou, a man who knew Russian and was well-informed in Russian traditions and knew the mentality of the local population.

The situation was complicated: on the eve of the winter, the city remains 300 thousand without water, electricity, transport, products, telephone communications. From the hospitals all equipment was taken out. Before Pintia and the 16 officials whom he brought, there was a difficult task - in the shortest possible time to establish life in the city. Amazingly, they succeeded. By July-August 1942, living standards in Odessa, at many points (and perhaps for all) exceeded the pre-war period. How it was done.

Competent management played an important role. The Romanians immediately rewrote all who could do something with their hands - engineers, doctors, technicians, and attracted them (for money) to set up city functioning systems. Then they included green light for private entrepreneurship. Private shops, restaurants, cafes, hairdressers, repair companies began to open hundreds. From the moment of the communist coup, it has been 24 years, since the NEP - 12-13 years. There were many people who knew what a private business was. Moreover, Romanians spent restitution if he documented confirmed that it belonged to the revolution or production department store - they returned. It is absolutely clear that if communist authorities could be overthrown at this time, the standard of living would rise very fast. There were still a lot of people there.

Under the conditions of the occupation regime and the new procedures introduced by the Romanian administration theaters became a breath of air for the people who remained (often not at their own will) in the occupied city, since not all could be evacuated - it was accessible primarily to the party elite, and not simple city residents. Eyewitnesses of events mention the queues to the port, which began from Pushkin Street. People stood along the Customs downhill. In occupied Odessa there were about two hundred and fifty thousand people. All of these people had to survive somehow and the cultural life which did not stop helped them to live in another conditions. The contemporary would be surprised that in the newspapers of that period along with the reports and orders of the occupation commanding intended to instill a general fear of a new regime, in particular those that concerned the destruction of Jews, one could also see announcements of performances, photographs of smiling citizens, information about their daily worries and everyday life. Literary evenings, exhibitions, premieres, productions, reviews, celebrity performances - these news stories created the illusion of peaceful life.

It is noteworthy that nobody forced the Romanian language artists. All works of world classics were shown in Russian translations. But the posters were printed in Romanian: «Corsarul», «Lacul lebedelor» (ballet «Corsar» and «Swan Lake»), «Mireasa tarului» (opera «Tsar's Bride»).

On October 27, 1941, the the first daily newspaper «Odesskaya Gazeta» was published. Later the newspapers «Our Days», «Bell», «The Voice», which covered the glamorous life of the city, began to be published. During the war, even some poetry books by S. Yesenin, M. Gumilev, Odesa poet Zhdanovich, and some others were even published in Odessa.

There was also a spectacular art. In particular in the occupied Odessa thirteen theaters were opened including small creative associations. There were also those that combined different musical genres (opera included), drama, circus art. However, Odessa's opera and ballet theater won the greatest honor among the residents of Odessa at that time and the guests of the city. 
In the occupation press it was reported that in the occupied Odessa the first production was the opera «Eugene Onegin». During the premiere of the hall was filled up with a blanket. In addition to it later the audience saw the well-known operas «Aida», «Tosca», «Rigoletto». The Romanians and Germans came to Odessa to listen to the operas "Boris Godunov», «Faust», «Eugene Onegin», to watch ballets «Swan Lake», «Sleeping beauty». But the opera «Dream at the Winter Night» by T. Mushashescu and the ballet «Wedding in the Carpathians» by P. Konstantinescu had no success (Informatsionnyiy gorodskoy portal «Odesskaya jizn»).

In opinion of the well-known Odessa citizen Machayne Poisner the Romanians avoided of frank propaganda performances. This was proved by the shows permitted to put on. The occupation authorities dictated their rules. There were several performances in the theater a day usually at thirteen o'clock and sixteen o'clock. At the same time the first show had to be the performance of the German or Romanian authors. After that - Russian or Ukrainian performances. All theater teams,scenery and costumes have remained since pre-war times (Poizner, p. 137).

In summer of 1942 guest artists flooded in occupied city. There were mainly Romanian and German ones. The Bucharest theater «Kerebush», under the direction of Tudor Mushatec, established a unique record: only in 1942, its theater troupe visited Odessa four times. The famous conductor B. Molinari came from Italy.

During the specified period the Odessa Conservatory restored its work. The director was the former singer of the Mariinsky Imperial Opera Lydia Lipkovska (Iz istorii Odessyi, 2018).

The artists forced to live abroad returned to occupied Odessa. Except the Odessa Opera and Ballet Theater the Theater of Pop, Theater of Chamber Operetta «Grotešk» began to work in the city. In April 1942, on the street. Greek, 48 famous artist Vasyl Vronsky opened the Theater of Russian Drama and Comedy with the production of «Auditor» Gogol. A local actor Ancharov opened the Russian operetta. The Romantic Theater was opened by a group of actors who moved from occupied Kiev. The Children's Garden Theater was founded, it was led by R. Ranevskaya from Munich (Iz istorii Odessyi, 2018).

In general the life of the occupied Odessa is an ambiguous and controversial period that has been studied little. Especially it concerns the cultural life of the city. It should be noted that in the period under study theater's repertoire was often changed. The posters were full of premieres being visited by Romanian and German officers. As far as an intelligent Odessa public it was the most numerous (Iz istorii Odessyi, 2018).

Theater's tickets were not very expensive. Many city's residents could buy the cheapest theater places. In the conditions of the occupation regime in theaters of Odessa leading European artists performed shows by well-known opera singers. There were the famous Italian tenor Luigi Magistretti, soloist of the Milan opera Neonila Balioz, Peter Leschenko. Odessa artists and theater teams also traveled on tour with permission of the occupation authorities. This is evidenced by articles and messages on the pages of the "Odessa newspaper» (Informatsionnyiy gorodskoy portal «Odesskaya jizn», 2018).

The Odessa Opera and Ballet Theater was attended by prominent European figures and representatives of the Romanian occupation authorities.

Thus during the whole period of the Romanian occupation the Odessa Opera and Ballet Theater continued to operate uninterruptedly. During that period the peculiarity of the theater's activities was that the team worked continuously. The theater's team had to take into account the realities of the occupation regime (Teatr $\mathrm{v}$ period Velikoy Otechestvennoy voyny, 2018). 
The activities of the Odessa Opera House were described by articles posted on the pages of occupation newspapers in July 1941 - August 1942.

In the edition of «Odesskaya Gazeta» on January 20, 1942, the performance «Toska» played at the Odessa Opera and Ballet Theater was rated as a big event. The author of the article reported on the premiere of «Toska» held in a special setting: conducted by the first guest from the Romanian artistic world Professor K. Lazar. He was greeted by the audience and artists. He performed the show with temperament and enthusiasm (Odesskaya gazeta, 1942, № 32, p. 3). The authors of the articles of «Odessa newspaper» have always adhered to the style of the submission of this or that information because the censorship could not give permission to publish the article.

In the same way another newsboy reported on P. Tchaikovsky's «Swan Lake» ballet. It was held on January 27th of that year on the top artistic level. In the opinion of the author of the newspaper reports the performance was the result of the serious, thoughtful work of the actor's team. The ballet master A. Terekhov, referred to further, was able to rally talented ballet actors in a friendly ensemble. The main parties were performed by V. Lesnevsky and A. Pershchov. It is significant that the premiere of «Swan Lake» took place on January 27th - on the day of the great national holiday of the Romanian people (Odesskaya gazeta, 1942, № 29, p. 3).

In the period of occupation the work of theater gave a significant profit to the budget of the city.

Besides this fact there was introduced a special tax at the rate of $3 \%$ of the ticket price by the Odessa city occupation municipality from January 25,1942 . It concerned theaters and other entertainment facilities such as exhibitions, museums, the Theater of Opera and Ballet, drama theaters, symphony concerts, lectures, folk festivals and public gardens and parks. The same tax on the ticket price there was set in cinemas, theaters of miniatures, comedies and operettas, circus, at literary and musical evenings, in zoological gardens and animals. On pop performances, dance venues, dancing evenings, various sports, racing, boating, roundabouts and other entertainment the tax was $10 \%$ of the ticket price. Fees were paid free of charge: Visitors to scientific and art museums, exhibitions, lectures and evenings, performances, cinema sessions and other entertainments arranged with a charitable purpose or a closed type of military command, educational institutions, resorts, sanatoria, rest homes for their patients exempted from paying taxes.

The administrators of the theaters and other institutions were required to pay the collected tax to the financial management of the municipality within a three-day period (Odesskaya gazeta, 1942, № 34, p. 3).

Despite the difficulties encountered in the occupied city the artists tried to depart from reality and plunge into the world of art in presenting for spectators the best models of domestic and world opera and ballet.

In one of the Odesa's newspaper issues the play «Traviata» was dealt with a historian who researched theatrical activities in the USSR Prof. B. Varneka. He expressed his thoughts about the theater past of the Odessa Opera and Ballet Theater and about its prospects. He said that the theater had been on the right way because its scene masters knew and understood their tasks. Undoubtly it allowed to create a truly, highly cultured business putting your soul (Odesskaya gazeta, 1942, № 43, p. 3).

As state above the Odessa Opera and Ballet Theater had weight among Romanian artists and intellectuals. So Romanian artists visited for theater tour too. 
To win the support of city's intellectuals the Romanian occupation authorities directed the Odessa residents to learn the traditions of Romanian musical art and culture the Romanian. On February 22, 1942, there was a message in the "Odessa newspaper» on behalf of Transnistria's Governor Professor Georges Alexisyan in Odessa where it was reported about wish of the Governor in Odessa to introducethe public with samples of Romanian music, as well as the skills of European musicians of performers. There were planned a number of tours. The concerts of the famous pianist Mr. Ion Filionescu and the symphony conductor, Paul Constantinescu took place in March. It was reported, that «...he program of this concert will be devoted exclusively to the works of Romanian composers. The director of the Musical Academy in Bucharest, the conductor, Mr. Michael Zhora, will perform in front of the Odessa audience» (Odesskaya gazeta, 1942, № 43, p. 3). In addition, it was announced that Fliria Kansari, the choreographer of the Romanian Opera in Bucharest, should arrive in Odessa, who will perform the two-act ballet «Wedding in the Carpathians» by composer P. Konstantinescu, whose music is «an example of Romanian folk folklore». Also, in this newspaper there was information that in May Odessa well-known violinist George Enescu will visit Odessa. All of these concerts will be held in the premises of the Odessa Opera and Ballet Theater (Odesskaya gazeta, 1942, № 43, p. 3).

In March 1942, the activities of the Odessa Opera and Ballet Theater increased. In studying the reports of the Odessa newspaper we got historical information that on March 25 and 29, 1942, the opera «Traviata» (for J. Verdi's music) was being planned to be shown in this theater. The role of Violetta in the performance was performed by Lydia Lipkovska, a Ukrainian drama singer, «one of the most outstanding artistic figures» (Odesskaya gazeta, 1942, № 56, p. 3).

In the same newspaper it was reported that on March 30, 1942, the ensemble of the Odessa Opera and Ballet Theater in the amount of 70 people will go on tour to the city of Kherson with the operas «Rigoletto», «Traviata» and «Madame Butterfly». As part of the ensemble of the artist T. Yegunova, N. Savchenko, N. Topciy and others conducted by N. Chernatyany as well as a part of the choir, orchestra and ballet. The ensemble of the theater intended to stage performances until April 4th (Odesskaya gazeta, 1942, № 56, p. 3).

In April 1942 in spite of the difficult conditions of the occupation regime the theater team prepared and played a series of performances. It should be noted that Ukrainian artists participated in plays On April 5, 1942, of the Odessa Opera and Ballet Theater. On April 5, 1942 the play «Traviata» took place with the participation of L. Lipkovskaya. She gave two performances The newspaper reported on her talent and of the artistry of its performance (Odesskaya gazeta, 1942, № 61, p. 3).

In the middle of April 1942 it was reported that in Odesa there was a «peculiar, melodious» performance of the opera «Demon» during which the actors were able to show themselves fully. It was stressed Tamara's party by actress V. Hubert in this performance: «It was pure and musical, and she led the party and produced a lot more artistic style in it». The author of article expressed opinion that Demon's party «performed well and stylishly by N. Savchenko is demonstrating one of the best samples of expressive singing filled of bright and compact sound (Odesskaya gazeta, 1942, № 64, p. 3).

There were another some opera soloists came to the occupied Odessa. Odessa residents remembered the performances of the Italian tenor L. Magistratti and the soloists of the Milan opera N. Balioz, accept the Bucureşti opera solist M. Chebotaru, the singer V. Popova and L. Lipkovskaya who was the former partner of Fedor Shalyapin. L. Lipkivska came from 
Romania and after her concerts he stayed in Odessa to live and work. As was reported in occupational press the performances of Petr Leshchenko had the greatest success among the inhabitants of the city.

There was the information that on April 8, 1942, that a new ballet «Wedding in the Carpathians» had been staged bythe theater. It was reported that the choreographer of this ballet was Ms. F. Kansari. From the Bucharest Opera. In October 1941 the show of this performance was failed but in April, 1942, it took place with succes. Moreover, Ms. F. Kansari «showed in her work a delicate taste and great skill, beautiful knowledge of the choreographic folklore of Romania, the rituals and customs of the Romanian peasants and the life of the Carpathian village. The ballet was also attended by: the premiere ballet by G. Leshnikov, the stories by A. Terekhov and A. Karsavina» (Odesskaya gazeta, 1942, № 64, p. 3).

From press we know about the «cultural life» of the invaders. In May, at the Odessa Opera and Ballet Theater, there were the concerts with the participation of artists from the German Army. The executives were officers and soldiers: Fritz Gallen-tenor (Berlin), Edgard Daubits - conductor (Leipzig), Otto Fricke - radio conductor (Berlin), Werner Liebh - drama artist (Dusseldorf), military choir part number 36952 and orchestra under the direction Chief Conductor of the Theater N. Chernyatynsky. There was two-part theater concert program. Overtures to the opera «Magic Arrow» (an orchestra under the direction of O. Fryke) was the first and then an organ prelude by S. Prokofiev was performed by E. Daubitsa (Odesskaya gazeta, 1942, № 72, p. 3).

A great interest among city’s intelligentsia was aroused by the premiere of a mosaic of two ballet fragments and the third act of Borodin's opera «Prince Igor («Polovtsian State»), which was held at the Odessa Opera and Ballet Theater. In a peculiar style the author of the show described the one-act ballet «Clock» (music by A. Ponkeilli). It was reported that the ballet «on a fairly primitive dragonfly canvas with a great taste embroidered with a very diverse dance pattern». The writer of article pointed out that the choreographer A. Terekhov had achieved undoubted success in working with the corps de ballet. «It is particularly evident in the dances of the «Polovets state» «as» high ballet qualities are combined with temperamental and expressive mimic scenes where the fast paced and bright, mottled oriental costumes are sustained (Odesskaya gazeta, 1942, № 78, p. 4).

Odessa Opera and Ballet Theater and the Lady Charity Committee of the city municipality periodically arranged joint charity concerts. One of these concerts took place on May 22, 1942. The concert was held in a large concert hall of the municipality. The money funds from that concert were directed to the poor families of Odessa. The next actors took part in the concert: V. Hubert, T. Egunova, T. Murzayeva, V. Popova, L. Malia, A. Ayarov, N. Dynaard, N. Savchenko, N. Topchiy. The ballet soloists: R. Kaidanova, O. Krasnoshchok, V. Pershchova, N. Poppandopoulos, O. Terentieva, L. Gont, P. Karsavin, V. Lesnevsky danced. The quartet was played by O. Kaversnova (violin), I. Pokrovsky (violin), N. Poppel (cello), G. Khramova (alto). There were involved drama artists: V. Vronsky, A. Otashevsky, B. Dikansky, I. Lopatnikov. Musical accompaniment was provided by the concertmaster of the opera P. Silkina, R. Kovalchuk, I. Kirpotina, the program was led by N. Bagryantsev (Odesskaya gazeta, 1942, № 84, p. 3).

At the end of May in the Odessa newspaper it was reported that it should be acquained the German army with the works of Russian composers. The administration of the Reichskommissariat «Ukraine» had entered into an agreement with the directorate of 
the Odessa Opera and Ballet Theater to do two tours in the city of Nikolaev where those shows were to take place on 4 and 5 August 1942. The ballet «Swan Lake» (music by P. Tchaikovsky) and a collective performance were planned to play: The Act of the «Tsar's Bride» opera (music by M. Rimsky-Korsakov), Act II from the opera «Eugene Onegin» (music by P. Tchaikovsky), III act «Polovtsy the state from the opera «Prince Igor» (A. Borodin's music). The participants of the tour were planned to be: conductor N. Chernyatynsky, choreographer A. Terekhova, 7 representatives of the artistic management of the theater, 12 soloists, including V. Hubert, N. Popova, N. Savchenko, N. Topciy, 50 ballet actors, among them B. Pervschova, R. Kaidanova, O. Krasnoshchok, V. Lesnevsky, L. Gont, P. Karsavin, 20 artists of the choir (Odesskaya gazeta, 1942, № 137, p. 3).

In summer of 1942 a set of young singers has been announced on the initiative of the Governor of Transnistria G. Alexeyny to form a new theater team of young artists to add the leading team. It was supposed to interested citizens of Odessa to take participation in that compettion too. Young artists who found vocal data were given the opportunity to work with experienced directors and conductors.

In the summer of the same year in the life of occupied Odessa there was another event, which was covered on the pages of the occupation press. It was reported that on Tuesday, June 21, at 16:00. 30 minutes, in the Odessa theater of opera and ballet in a solemn atmosphere there was the hundredth performance (Odesskaya gazeta, 1942, № 104, p. 3).

Governor of Transnistria G. Alexeyan attended the event. At the opening of the ceremonial the chorus was accompanied by the orchestra performed Romanian, German and Italian hymns. After that a brief report on the work of the theater was made by his director and artistic director prof. V. Seliavin. There were staged two ballet scenes from ballet «Wedding in the Carpathians» by F. Kansar. The author of the ballet composer Paul Constantinescu conducted himself (Odesskaya gazeta, 1942, № 104, p. 3).

By creating conditions for theater activities the Romanian occupation authorities used them to propagate among the population their aims and ideas. For example, the local section of the Ministry for the Promotion of the Occupation Authority used theater posters to disseminate that information or propaganda material. There were several places where people gathered in droves on the street near the Opera and Ballet Theater to read posters. In April 1942 one of the issues of newspaper described a crowd of people who looked at something on a large board on the wall of the theater. It was often possible to see glued photographs. Each of them was accompanied by a literal signature. The photos were extremely convincing. For example, on one of them - «the mountain of corpses ... The bodies are bombarded on each other ... People are not just killed, they are cruelly tortured...». The inscription said that these were the corpses of people shot by the Bolsheviks in certain places. That's no doubt that in this way the Ministry of Public Procuratoration extended its anti-Soviet military propaganda (Odesskaya gazeta, 1942, № 64, p. 3).

Conclusions. So, analyzing the activities of the creative team of the Odessa Opera and Ballet Theater during the Romanian occupation regime of 1941 - 1942, it should be noted that part of the theatrical intelligentsia, for various reasons and circumstances, could not be evacuated to the depths of the USSR. To survive in the difficult conditions of the occupation regime, the actors were forced to continue to set performances. It was a real theatrical art, which kept domestic traditions and borrowed the experience of the leading luminaries of opera and ballet of world level.

This period of the Odessa Opera and Ballet Theater is an important part of the heritage of the national and world theater art. Of course, it is possible to evaluate differently the actions 
of those who remained in the occupied territory. But despite all, the work of the collective of the Odessa Opera and Ballet Theater, whose performances were attended by many people during the war and occupation, testified of the level of contemporary national art and culture in general.

The activities of the Odessa Opera Theatre during the marked period are just a fragment of the city's theatrical life. In order to complete the full picture of the cultural life of Odessa during the Romanian occupation, it is necessary to continue the research of the Theater of Chamber Operetta Grotesque, the Theater of Russian Drama and Comedy, the Russian Operetta Theater, the Romantic Theater, the Children's Theater Garden and others.

Acknowledgments. The author of the publication express my sincere gratitude director and employees of the State Archives of Odessa region for support and assistance in search of archival material.

Funding. The authors received no financial support for the research, authorship, and/or publication of this article.

\section{BIBLIOGRAPHY}

Astafeva, E. (2018). Ya vam ne spoyu za vsyu Odessu: istoriya Odesskogo opernogo teatra [I won't sing for you all over Odessa: the history of the Odessa Opera House]. Diletant. Istoricheskiy jurnal dlya vseh. 24 noyabrya 2015. URL: http://diletant.media/articles/26835240/ (Dostup k 17.10.2018) [in Russian].

Bolovan, I., \& Pop, I.-A. (2005). Istoriya Rumynii [History of Romania]. URL: http://www.pseudology.org/mid/Rumynia/PopBolovan_IstoriaRumynii2a.pdf (Dostup k 21.12.2018) [in Russian].

Derzhavnyi arkhiv Odeskoi oblasti [State archive of Odessa Region-SAOR]

Dizanova, A. V. (2016). Okupatsiinyi rezhym v ukrainskomu Podunav'i (1941 - 1944 rr.) [Occupation regime in the Ukrainian Danube region $(1941$ - 1944)]. Naukovyi visnyk Izmailskoho derzhavnoho humanitarnoho universytetu. Seriia «Istorychni nauky», 34, 48-53. [in Ukrainian].

Informatsionnyiy gorodskoy portal «Odesskaya jizn» (2018). Informatsionnyiy gorodskoy portal «Odesskaya jizn» [Information city portal «Odessa Life»]. URL: http://odessa-life.od.ua/article/1799okkupaciya-odessy-drugoi-vzglyad (Dostup k 24.10.2018) [in Russian].

Istoriya Bessarabii i Yuga Ukrainyi (2016). Istoriya Bessarabii i Yuga Ukrainyi [History of Bessarabia and the South of Ukraine]. URL: http://docs.ahistory.info/odessa-1941-1944/ (Dostup k 27.10.2018) [in Russian].

Iz istorii Odessyi (2018). Iz istorii Odessyi: kulturnaya jizn $v$ okkupatsii. [From the history of Odessa: cultural life in the occupation] URL: http://viknaodessa.od.ua/news/?news=68898 (Dostup k 18.10.2018) [in Russian].

Maksymenko, V. S. (2010). Gorodskoy teatr Odessyi: 1809 - 2009 / [Odessa City Theater: 1809 - 2009] / Odessa: Astroprint. 456 s. [in Ukrainian].

Forsythe, M. (1985). Buildings for Music. Cambridge University Press. 344 p. [in English].

Odeskyi opernyi teatr. Fotoalbom (1969). Odeskyi opernyi teatr. Fotoalbom [Odessa Opera House] / Tekst A. Artomov, I. Ihnatkin. Kyiv: «Mystetstvo», 24 p. [in Russian].

Odesskaya gazeta [Odessa newspaper]. 1942, № 29, 20.01,3. URL: https://libraria.ua/numbers/188/ [in Russian].

Odesskaya gazeta [Odessa newspaper]. 1942, № 32, 27.01, 3. URL: https://libraria.ua/numbers/188/ [in Russian].

Odesskaya gazeta [Odessa newspaper]. 1942, № 34,31.01, 3. URL: https://libraria.ua/numbers/188/ [in Russian].

Odesskaya gazeta [Odessa newspaper]. 1942, № 43, 22.02, 3. URL: https://libraria.ua/numbers/188/ [in Russian].

Odesskaya gazeta [Odessa newspaper]. 1942, № 56, 25.03, 3. URL: https://libraria.ua/numbers/188/ [in Russian]. 
Odesskaya gazeta [Odessa newspaper]. 1942, № 61, 05.04, 3. URL: https://libraria.ua/numbers/188/ [in Russian].

Odesskaya gazeta [Odessa newspaper]. 1942, № 64, 14.04, 3. URL: https://libraria.ua/numbers/188/ [in Russian].

Odesskaya gazeta [Odessa newspaper]. 1942, № 72, 30.04, 3. URL: https://libraria.ua/numbers/188/ [in Russian].

Odesskaya gazeta [Odessa newspaper]. 1942. № 78, 10.05, 4. URL: https://libraria.ua/numbers/188/ [in Russian].

Odesskaya gazeta [Odessa newspaper]. 1942, № 84, 21.05, 3. URL: https://libraria.ua/numbers/188/ [in Russian].

Odesskaya gazeta [Odessa newspaper]. 1942, № 104, 23.06, 3. URL: https://libraria.ua/ numbers/188/ [in Russian].

Odesskaya gazeta [Odessa newspaper]. 1942, № 137, 26.07, 3. URL: https://libraria.ua/ numbers/188/ [in Russian].

Poizner, M. B. (2004). Okupatsiia. Odesa: 1941 - 1944 rr. Dokumenty ta materialy iz zibrannia Mykhaila Poiznera [Occupation. Odessa: 1941 - 1944. Documents and materials from the collection of Michael Poizner]. Odesa: Druk, 376 p. [in Ukrainian].

Salata, O. (2018) Informatsiine protystoiannia mizh Nimechchynoiu ta SRSR v istoriohrafii [Information confrontation between Germany and the USSR in historiography]. Kyivski istorychni studii, 1 (6), 56-62. doi.org/10.28925/10.28925/2524-0757.2018.1.52-62 [in Ukrainian].

Samoilov, F. (2010) Odeskyi natsionalnyi akademichnyi teatr opery ta baletu [Odessa National Academic Opera and Ballet Theater]. Entsyklopediia istorii Ukrainy: u 10 t. Kyiv: Naukova dumka, T. 7, 547. [in Ukrainian].

Teatr v period Velikoy Otechestvennoy voyny. (2018) [Theater during the Great Patriotic War]. URL: http://archodessa.com/all/new-opera-theatre-history-world-war/ (Dostup k 09.08.2018) [in Russian].

The article was received on January 12, 2019. Article recommended for publishing 24/02/2019. 